\title{
A Simulated Electronic Availability Study of Serial Articles through a University Library Web Page
}

\section{Thomas E. Nisonger}

\begin{abstract}
Availability tests as traditional collection evaluation and library performance measures and their application to electronic resources are explained in this article. A 500-item sample of serial citations was drawn from scholarly journals in 50 disciplines, evenly divided among the sciences, social sciences, humanities, professional fields, and interdisciplinary areas to simulate the needs of Indiana University-Bloomington researchers. It was found that 65.4 percent of the items were electronically available through the library Web page. The electronic availability rate was highest for professional fields, items in the English language, and items published since 2000. The majority of instances of nonavailability occurred because the journal title was not accessible through the Web page.
\end{abstract}

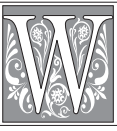

hile the term "availability" can have multiple meanings in both a library and a nonlibrary context, an "availability study" represents a well-established method for evaluation of library collections as well as overall library performance. These studies test whether desired materials (typically books) are shelved in the correct location and can be immediately retrieved by the patron. As will be demonstrated in the following section, more than 90 investigations of availability, dating as far back as the 1930s, have been reported in the library and information science literature. A formal "availability study" must be distinguished from other frequent mean- ings of the word in the literature, such as holdings in a library, a journal title's presence on the Web, or the obtainability of a book in the out-of-print market.

Availability studies have been compared to systems analysis, as a library may be viewed as a system with the purpose of immediately providing desired documents to its clients. An availability study tests how well the system is performing that function and can identify specific causes of failure. ${ }^{1}$ Also, an availability study is considered a measure of user satisfaction, predicated on the assumption that finding a sought-after item results in a happy library patron. ${ }^{2}$ Indeed, availability studies have occasion-

Thomas E. Nisonger is Professor Emeritus in the School of Library and Information Science at Indiana University; e-mail: nisonge@indiana.edu. The author gratefully acknowledges his graduate assistants at the Indiana University School of Library and Information Science, Suzanne S. Switzer and Jennifer A. Brosek, who assisted in a variety of capacities. He also thanks Mary Popp of Indiana University's Herman B Wells Library for valuable advice regarding the project and Stephen E. Wiberley, Jr., Professor and Bibliographer for the Social Sciences, University of Illinois at Chicago Library, who provided comparative data gathered at his library. 
ally been termed "satisfaction studies." ${ }^{3}$ Stated somewhat differently by Herbert S. White, "the user doesn't care that the library owns a million books, if he can't find the one he wants." ${ }^{4}$

The overwhelming majority of availability studies have been for known-item searches. In other words, the availability of a specific document or item (usually a book and less frequently a journal article) is tested. A distinction must be made between a "real" and "simulated" approach. The majority of availability investigations would be considered "real" because they were based on self-reports by library patrons who were actually trying to locate desired items on the shelves, while a minority have been "simulated" investigations in which the shelf availability of a set of items (presumed to represent user needs) is tested by the investigator.

During the 1970s, Paul B. Kantor developed a branching method for analyzing in real studies why a desired item was unavailable. He outlined four branches or barriers to the user not obtaining the desired item: acquisitions (the desired item was not acquired by the library); circulation (all copies are in circulation); library operations (the item is not in the correct shelf location because it is shelved incorrectly, lost, sitting on a book cart, or any of a number of other reasons); and the patron (who cannot locate a correctly shelved item). ${ }^{5}$ Other branches were used in later modifications of Kantor's method: the catalog (the item cannot be found in the catalog or the call number is copied incorrectly) ${ }^{6}$ and the bibliographic (the patron has an incorrect or incomplete citation). ${ }^{7}$

A number of library and information science authors have advocated an expansion of the traditional availability model, which was developed and primarily used for print resources in a single library. In the mid-1990s, Neal K. Kaske called for the creation of "a new valid measure of materials availability" for the "'virtual' information environment," in which patrons then used the Internet to check the holdings of multiple libraries via their Online Public Access Catalogs (OPACs) to locate (and request through interlibrary loan) a desired title. Kaske proposed a three-part expansion of the availability concept to include: searching multiple libraries, how soon the item is needed, and the format of the information. ${ }^{8}$ More recently, Thomas E. Nisonger advocated a redefinition of availability to mean quickly obtaining an item electronically rather than physically on the library shelf. He wrote, "While many patrons may no longer expect the immediate gratification of finding an item on a library shelf, they may nevertheless expect immediate gratification in locating it electronically." ${ }^{\prime 9}$

Accordingly, this investigation has adapted the traditional availability concept to a Web-based electronic environment. Instead of testing whether a print item is on the shelf, it measures the extent to which the full text of electronic documents can be quickly retrieved on a computer screen. Yet, in both print and Web environments, the fundamental research question remains the same: how well is the library performing in providing needed documents to its patrons? Accordingly, this article reports an investigation of the availability of 500 serial citations, selected to simulate the needs of researchers on Indiana University's Bloomington campus, through the Web page of the Herman B Wells Library.

\section{Literature Review}

This section provides a review (by no means comprehensive) of the literature relating to availability studies in libraries and the use of citations in the evaluation of library collections and electronic resources. The earliest known availability study was conducted at the Iowa State College (now renamed Iowa State University) Library and described in 1934 by H.V. Gaskill, R.M. Dunbar, and C.H. Brown. ${ }^{10}$ Since then, according to two literature reviews, more than 90 investigations of availability have been reported. 
In 1986, John Mansbridge identified approximately 40 availability studies published from 1934 through the early 1980s. ${ }^{11}$ Nisonger recently supplemented Mansbridge's work by reviewing more than 50 investigations of availability (not including any already covered by Mansbridge) published from 1980 through 2001. Mansbridge indicates that approximately two thirds of the studies he analyzed were based on real users, ${ }^{12}$ while Nisonger identified 46 real compared to 8 simulated investigations. ${ }^{13}$

Nisonger's review identified availability studies conducted in eleven countries on all continents except South America and Antarctica. ${ }^{14}$ Examples of book availability analysis include investigations at the University of Zululand in South Africa, based on 353 searches, by Lindiwe E. Zondi; ${ }^{15}$ and at International Islamic University in Malaysia, based on 441 searches, by Sajjad Ur Rehman, Kokab Arif, and Abdous Sattar Chaudhry. ${ }^{16}$ More relevant to this article, a number of researchers have investigated the availability of journal articles or included them as part of a multiformat study. Availability data for print journal or serial articles has been reported for: 2,056 searches at the University of North Carolina at Chapel Hill Health Sciences Library by Julia Shaw-Kokot and Claire de la Varre, ${ }^{17}$ 127 searches at Adelphi University by Anne Ciliberti and others, ${ }^{18}$ an unspecified number of searches at King Fahd University of Petroleum and Minerals in Saudi Arabia by Abdus Sattar Chaudhry and Saleh Ashoor, ${ }^{19} 139$ searches at the University of Western Australia by Melanie Harris and Imogen Garner, ${ }^{20} 483$ searches at the University of New Mexico by Jan Bachmann-Derthick and Sandra Spurlock, ${ }^{21}$ and 297 searches at the East Tennessee State University College of Medicine by Jennifer Eugenie Roberts. ${ }^{22}$

To cite illustrative examples of simulated studies, Roger Edward Stelk and F.W. Lancaster investigated the shelf availability of two 450-item samples, taken from the shelflist and from a list of recently circulated titles, at the University of Illinois at Urbana-Champaign Undergraduate Library. ${ }^{23}$ Focusing on serials, Chaudhry and Ashoor investigated the availability of 100 serial titles from Magazines for Libraries at King Fahd University of Petroleum and Minerals. ${ }^{24}$ Susan Steynberg and S.F. Rossouw tested the availability of a 307-item sample of journal articles by South African biomedical researchers in the University of Cape Town Medical Library. ${ }^{25}$

Citations have frequently been used as checklists for collection evaluation for well over 150 years. It should be briefly explained that, in the checklist method, a list of items is checked against the holdings of a library or consortium, as indicated by the catalog (previously the card catalog, now the OPAC). The percentage of items held is considered an indicator of collection strength and quality. For a concise summary of this approach along with an outline of its advantages and disadvantages, see Barbara Lockett's Guide to the Evaluation of Library Collections. ${ }^{26}$ In the late 1840s, Charles Coffin Jewett, Assistant Secretary of the Smithsonian Institute, used citations from leading mid-nineteenth century textbooks as a checklist (although he did not use that term) to evaluate the Smithsonian's library. ${ }^{27}$ During the 1950s, William L. Emerson drew citations from 23 engineering doctoral dissertations to evaluate the Columbia University Engineering Library. ${ }^{28}$ In the early 1980s, Nisonger checked citations from six political science journals to evaluate the political science collections of Catholic, George Mason, George Washington, Georgetown, and Howard university libraries. ${ }^{29}$ Reba Leiding used citations in 101 undergraduate honors theses written at James Madison University to evaluate the library's collection. ${ }^{30}$ Many other examples could be listed. Quite recently, Nisonger reviewed studies that used citations from journals, textbooks, dissertations, and theses, as well as faculty publications, as collection evaluation checklists. ${ }^{31}$ 
In a similar vein, citations have been used as checklists for evaluation of indexing and/or full-text coverage of electronic databases. For example, David C. Tyler, Signe O. Boudreau, and Susan M. Leach used 6,170 citations from core communication studies journals to evaluate the indexing coverage of three communication studies databases (ComAbstracts, ComIndex, and Communication Abstracts) plus five multidisciplinary databases, including Academic Search Elite and Web of Science. ${ }^{32}$ Nisonger used 1,166 citations from Library Resources and Technical Services and Collection Building to test the full-text library and information science coverage of the Library Literature and Information Science Full Text and the EBSCOhost Academic Search Premier databases. ${ }^{33}$

Similar to this research project, at least three studies have used citations to investigate availability through library Web pages rather than focusing on coverage in specific databases. Thomas Schaffer checked the availability of 368 journal article citations from publications by Texas A \& M University psychology faculty in 26 electronic databases or resources licensed by that university's library. ${ }^{34}$ Jason S. Price analyzed the availability of 861 citations from recent publications by the Department of Biology faculty through the library Web page of the Claremont Colleges. ${ }^{35}$ In an apparently unpublished paper posted on the Web, Steven J. Squires, Margaret E. Moore, and Susan H. Keesee checked the online availability at the University of North Carolina at Chapel Hill Health Sciences Library of 400 citations from course reading lists and faculty publications plus faculty publications themselves. ${ }^{36}$

One should briefly mention some other strategies for investigating the availability or accessibility of electronic resources on the Web. Bradley Brazzeal and Amanda Clay Powers investigated the electronic availability of 47 agronomy journals listed in the Journal Citation Reports at 8 ARL libraries. ${ }^{37}$ Kathleen E. Joswick checked the electronic full-text coverage of 433 core psychology journals (that is, Social Sciences Citation Index source journals) in 8 general databases such as LexisNexis Academic and 4 psychology journal databases such as PsyArticles. ${ }^{38}$ Some studies (for example, Dana M. Caudle and Cecilia M. Schmitz, who analyzed the Web sites of 99 ARL libraries) have addressed technical options, such as A to Z lists, OPAC entries, or links to find articles, for accessing electronic resources through the library Web page. ${ }^{39}$

Finally, while a significant literature exists about the evaluation of electronic database content by methods other than checking citations, the persistence of Web sites or links, citation patterns in numerous disciplines, and print journal subscription holdings, these topics are only tangential to this research project and thus beyond this review's scope.

\section{The Indiana University Bloomington: Campus and Libraries}

Indiana University was officially established (under the name State Seminary) in 1820 with classes beginning in Bloomington in 1824. The institution was renamed Indiana College in 1828 and then Indiana University in $1838 .{ }^{40}$ Bloomington is now frequently referred to as the "flagship campus" of the eight-campus Indiana University system, with other sites at Fort Wayne, Gary, Indianapolis, New Albany, Kokomo, Richmond, and South Bend. Note that the Indianapolis and Fort Wayne campuses are jointly administered with Purdue, while the Indianapolis campus has a small branch in Columbus, Indiana. In the fall 2007 semester, 38,990 students were enrolled on the Bloomington campus, composed of 30,394 undergraduates, 7,672 graduate, and 924 professional students. There were 1,943 full-time plus 366 part-time faculty as well as 90 professional librarians on the campus. ${ }^{41}$ There are 332 authorized degree programs on the campus, broken down into 3 technical certificates, 16 nontechnical certificates, 12 associate degrees, 110 baccalaureate degrees, 3 
professional degrees, 105 master's or specialist degrees, and, most pertinent to this investigation, 83 doctoral degrees. ${ }^{42}$

The Herman B Wells Library, named after a venerated former Indiana University president who, among other things, defended Alfred C. Kinsey's controversial research about human sexuality, is the central library on the Bloomington campus. Other noteworthy libraries on the campus include the William and Gayle Cook Music Library and the Lilly Library, focusing on rare books and manuscripts. The Library's OPAC, named IUCAT, provides access to the entire Indiana University library system as well as 21 different libraries and 11 Residence Hall Libraries on the Bloomington campus. During the time this research was conducted, the Indiana University Bloomington Libraries contained 6.6 million books in 900 languages, ranking 13th in collection size among Association of Research Libraries (ARL) members. ${ }^{43}$ More germane to this investigation, the IUB library system provided access to 400 electronic databases and 43,000 electronic journals. ${ }^{44}$

\section{Procedures}

This simulated study was based on a sample of 500 serial citations, randomly selected from scholarly journals in 50 different subject areas or disciplines. A sample size of 500 was chosen because Kantor recommended a 400- to 500-item sample, ${ }^{45}$ Blaine $\mathrm{H}$. Hall recommended distribution of 500 survey forms to obtain 400 useable searches for analysis, ${ }^{46}$ and Mansbridge's literature review identified 437 as the median sample size. ${ }^{47}$

The fifty subject areas were chosen after reviewing a list of Indiana University Bloomington's academic programs, the degrees offered, and student enrollment figures. In almost all cases, graduatelevel degrees were offered in the selected areas. The fifty subject areas were equally divided among five broad categories of academic endeavor: the sciences, social sciences, humanities, traditionally interdisciplinary areas (the word "traditional" is used because many areas of contemporary scholarship are now interdisciplinary), and professional fields.

The source journals for the 50 subjects or disciplines (one journal for each area) may be viewed as a judgment sample. The goal was to select high-quality researchoriented journals that Indiana University faculty and graduate students would be likely to use in their research and seek to access serial articles cited in the journals' footnotes. Selection priority was given to journals covering their entire field rather than a subdiscipline. The following methods were used to assist journal selection: journal reputation, publisher reputation, whether covered in the Journal Citation Reports (if covered, rank within its subject category by both impact factor and total citations received for each of the three most recent years), Magazines for Librar$i e s,{ }^{48}$ direct examination of the journal, and examination of Indiana University departmental or program Web pages to help assess departmental research focus. Note that all methods were not used for each journal selected. See Appendix A for the 50 subject areas and the source journal for each.

The first 2007 issue was located and 10 citations were randomly selected from at least 4 different articles, except in a few cases where only 3 articles contained citations. The searches were conducted in the researcher's office (which has a hardwired connection to the Indiana University Libraries Web page) at various times from approximately 9 A.M. to 6 P.M. Monday through Friday during a period of four and a half months from mid-April through late August of 2007. Searching was based on print copies of the original source articles with the randomly selected citations marked, so there would be no danger of a transcription error of the citation by the researcher. A four-step process, outlined below, was used to search for each randomly selected item:

1. The serial title was entered into the box entitled "Find a specific journal or newspaper online," accessed by selecting 
"Find Information" on the library Web page's main menu, and then clicking on "Online Full Text Journals." This search resulted in a menu (sometimes including false hits) of matches, which listed the years covered, the ISSN, and the database or collection containing the title. All databases were searched until the full text was retrieved on the investigator's computer screen (and reviewed for completeness). If the item was not located in full text, the investigator proceeded to step 2 below; if it was located, the researcher moved to step 3 to check library holdings in print or microform. Note that print and microformat holdings were checked for all items, regardless of electronic availability.

2. The journal title or ISSN plus the specific article's year, volume, issue, and starting page were entered into the box for a specific article search. Using the SFX by Ex Libris link resolver licensed by the Indiana University Libraries, this strategy would lead directly to the article, if available electronically. This resulted in success in only a few instances, as most electronically available items were retrieved in step 1. A 10-minute limit was placed on searching for the full-text item through the library Web page, predicated on the assumption that, if the document cannot be retrieved within 10 minutes, it is not immediately available. This tactic offers an easily quantifiable objective measure and is modeled upon the ap- proach used in traditional availability studies for print materials.

3. The journal title was searched in the Indiana University OPAC, termed IUCAT, as a final check to verify that an electronic version of the title was not available on the Bloomington campus and to record print or microform holdings for each item in the sample.

4. If a full-text electronic version was not located through the first three steps, a Google search was conducted under the sought-after article's author or authors plus title. In a number of instances, this step revealed that the citation in the source document was incorrect or that an article not accessible through the library Web page was freely available on the Web.

The raw results were initially recorded in an MS Word file by the researcher as the searches were conducted. Then an Excel file was created by his graduate assistant to facilitate tabulation by such variables as subject, language, publication date, and the journal's Library of Congress classification number. The two files were carefully reconciled to ensure that no data errors were introduced.

This methodology offers the following advantages:

- A reasonable simulation of the resources an Indiana University Bloomington researcher would likely to be seeking in electronic form through the library Web page

\section{TABLE 1}

Full-Text Electronic Availability of Simulated Sample

\begin{tabular}{|l|c|c|c|c|c|}
\hline \hline Category & Number & Available & Percentage & $\begin{array}{c}\text { Not } \\
\text { Available }\end{array}$ & Percentage \\
\hline Area Studies & 100 & 51 & $51 \%$ & 49 & $49 \%$ \\
\hline Humanities & 100 & 45 & $45 \%$ & 55 & $55 \%$ \\
\hline $\begin{array}{l}\text { Professional } \\
\text { Fields }\end{array}$ & 100 & 81 & $81 \%$ & 19 & $19 \%$ \\
\hline Sciences & 100 & 79 & $79 \%$ & 21 & $21 \%$ \\
\hline $\begin{array}{l}\text { Social } \\
\text { Sciences }\end{array}$ & 100 & 71 & $71 \%$ & 29 & $29 \%$ \\
\hline Total & 500 & 327 & $65.4 \%$ & 173 & $34.6 \%$ \\
\hline
\end{tabular}


- The potential bias of using citations from faculty publications or course syllabi (that is, available items may be more likely to be cited) is overcome ${ }^{49}$

- A focus is on the collection evaluation issue of whether the item is available on the Bloomington campus through the Indiana University Libraries Web page

- The random selection method results in interdisciplinary citations, reflecting the nature of contemporary scholarship.

\section{Results}

Table 1, organized by five broad categories, presents this investigation's basic results. Note that this categorization is based on the source journals, not the actual subject of the sought-after items, which often varied due to interdisciplinary citations. In total, 65.4 percent of the items were available (based on the criteria outlined above) through the Indiana University Web page. Wide variation in the availability rates among source journal category is evident. The two strongest categories were professional fields (81\%) and the sciences $(79 \%)$, followed by the social sciences $(71 \%)$. A far lower availability rate (51\%) can be observed for area studies/interdisciplinary areas (which will subsequently be referred to as "area studies"). The weakest category was the humanities, in which less than half the cited items were available electronically (45\%).

In addition, 18 items unavailable through the library Web page were obtained in full text through a follow-up Google search. If these were to be counted, the overall availability rate would increase to 69 percent and the rates by broad category would rise to 86 percent for the sciences, 84 percent for professional fields, 75 percent for the social sciences, 54 percent for area studies, and 46 percent for the humanities. However, it is uncertain how many library users would conduct follow-up Google searches and questionable whether the library should be credited for items located through Google (although its Web page does offer a link to Google) as they were not licensed by the library. Thus, the remaining analysis in this article will focus on the 65.4 percent of items available directly through the library Web page.

Why the variation among categories? A supposition that the humanities and area studies were the two weakest categories simply because the Indiana University Bloomington Libraries attach a low collecting priority to them is not a reasonable explanation because the library supports the campus's strong tradition of emphasizing both the humanities and area studies. As will be elaborated upon below, the language and age composition of the samples for each category partially explains the variation. Also, drawing upon Everett M. Rogers' diffusion of innovations theory, ${ }^{50}$ one is tempted to speculate that the speed at which an area is perceived to adapt to technology (the scientific areas as "early adopters" and the humanities as "laggards") influences vendor marketing of electronic resources.

Table 2 tabulates the explanations for nonavailability for the 173 items not immediately available through the Indiana University Libraries Web page. The most frequent explanation, accounting for more than three fifths $(62.4 \%)$ of the nonavailable items, was the fact that the title containing the sought-after citation was not electronically available (in other words, was not accessible through the library's Web page, either through licensing or a link to an open-access source). Indeed, nonavailability of the title itself was the most frequent reason for nonavailability in all five broad categories, ranging from 77.6 percent in area studies to 38.1 percent in the sciences. Next, in nearly a quarter of the instances of nonavailability $(23.1 \%)$, the title was actually available, but the citation was earlier than the available run. Indicating a consistent pattern across knowledge domains, this was the second most frequent explanation in each of the broad categories, ranging from 44.8 percent in social sciences to 8.2 


\begin{tabular}{|c|c|c|}
\hline \multicolumn{3}{|c|}{$\begin{array}{c}\text { TABLE } 2 \\
\text { Reasons for Nonavailability }\end{array}$} \\
\hline Reason & $\begin{array}{c}\text { Number of } \\
\text { Unavailable Items }\end{array}$ & Percentage \\
\hline Area Studies & 49 & $49 \% *$ \\
\hline Title not available electronically & 38 & $77.6 \% * *$ \\
\hline Citation earlier than available run & 4 & $8.2 \%$ \\
\hline Combination of factors & 2 & $4.1 \%$ \\
\hline Title available, but coverage not complete & 2 & $4.1 \%$ \\
\hline Citation later than available run & 1 & $2 \%$ \\
\hline Title available, but item not retrieved & 1 & $2 \%$ \\
\hline Title available, but wrong citation given & 1 & $2 \%$ \\
\hline Humanities & 55 & $55 \%$ \\
\hline Title not available electronically & 40 & $72.7 \%$ \\
\hline Citation earlier than available run & 10 & $18.2 \%$ \\
\hline Title available, but coverage not complete & 3 & $5.5 \%$ \\
\hline Citation later than available run & 2 & $3.6 \%$ \\
\hline Professional Fields & 19 & $19 \%$ \\
\hline Title not available electronically & 8 & $42.1 \%$ \\
\hline Citation earlier than available run & 6 & $31.6 \%$ \\
\hline Title available, but wrong citation given & 2 & $10.5 \%$ \\
\hline Citation later than available run & 1 & $5.3 \%$ \\
\hline Title available, but coverage not complete & 1 & $5.3 \%$ \\
\hline Title available, but item not retrieved & 1 & $5.3 \%$ \\
\hline Sciences & 21 & $21 \%$ \\
\hline Title not available electronically & 8 & $38.1 \%$ \\
\hline Citation earlier than available run & 7 & $33.3 \%$ \\
\hline Citation later than available run & 2 & $9.5 \%$ \\
\hline $\begin{array}{l}\text { Title available, but item required more than } 10 \\
\text { minutes to retrieve }\end{array}$ & 1 & $4.8 \%$ \\
\hline Title available, but item not retrieved & 1 & $4.8 \%$ \\
\hline Title available, but wrong citation given & 1 & $4.8 \%$ \\
\hline Title available, but searching error & 1 & $4.8 \%$ \\
\hline Social Sciences & 29 & $29 \%$ \\
\hline Title not available electronically & 14 & $48.3 \%$ \\
\hline Citation earlier than available run & 13 & $44.8 \%$ \\
\hline Title available, but item not retrieved & 1 & $3.4 \%$ \\
\hline Combination of factors & 1 & $3.4 \%$ \\
\hline Grand Total & 173 & $34.6 \%$ \\
\hline Title not available electronically & 108 & $62.4 \%$ \\
\hline
\end{tabular}




\begin{tabular}{|l|c|c|}
\hline \multicolumn{2}{|c|}{ TABLE 2 } \\
\hline \multicolumn{2}{|c|}{ Reasons for Nonavailability } \\
\hline \hline Reason & $\begin{array}{c}\text { Number of } \\
\text { Unavailable Items }\end{array}$ & Percentage \\
\hline Citation earlier than available run & 40 & $23.1 \%$ \\
\hline Citation later than available run & 6 & $3.5 \%$ \\
\hline Title available, but coverage not complete & 6 & $3.5 \%$ \\
\hline Title available, but item not retrieved & 4 & $2.3 \%$ \\
\hline Title available, but wrong citation given & 4 & $2.3 \%$ \\
\hline Combination of factors & 3 & $1.7 \%$ \\
\hline $\begin{array}{l}\text { Title available, but item required more than } 10 \\
\text { minutes to retrieve }\end{array}$ & 1 & $0.6 \%$ \\
\hline Title available, but searching error & 1 & $0.6 \%$ \\
\hline $\begin{array}{l}* \text { Percentage of sample that was unavailable } \\
* * \text { Percentage of unavailable items }\end{array}$ & & \\
\hline
\end{tabular}

percent in area studies. Tied for a distant third place (although not consistently third among the five categories) and each accounting for 3.5 percent of availability failures, were a citation more current than the available run and incomplete coverage for an available title-defined as cases in which the volume and issue were available without including the specific item. It is significant that almost 90 percent of nonavailable items could be attributed to the fact that the needed volume was not accessible through the Web page.

The remaining causes for electronic nonavailability were scattered among a variety of situations. Four failures (2.3\%) were due to an error in the original citation (remember that the search was based on a copy of the source article rather than a transcription of the citation by the investigator). The error was discovered through the follow-up Google search, and then the correct citation was verified to be electronically available through the library Web page. In 4 instances $(2.3 \%$ of failures), a theoretically available item was not accessible due to a retrieval error; in other words, clicking on an article or volume number would not lead to its display on the screen. Three failures $(1.7 \%)$ were caused by a combination of factors, such as an incorrect citation in combination with a faulty search strategy by the investigator. Finally, in one instance, the cited item was retrieved after the 10-minute limit had lapsed; and, in another, a searcher error (this investigator's) was responsible for not finding an electronically retrievable article due to an ineffective searching strategy (both representing $0.6 \%$ of failures).

How can Kantor's branching method, which identifies (for a print environment) barriers to finding the desired item, be applied to the results of this study? The "bibliographical branch" (beginning the search with an incorrect citation) accounted for 2.3 percent ( 4 of 173) of the retrieval failures because of a citation error in the source journal. Note that there were numerous other cases of source journal citation error that did not result in failed searches. The "acquisitions branch" (the desired item was not acquired), for which the electronic equivalent would be not licensing or linking to the item, represented the major barrier to electronic availability, causing 160 of the 173 (92.5\%) instances of nonavailability. The "circulation branch" (the sought-after item is in use) would usually not apply in the electronic world (except for netLibrary's one-book, one-user policy or a maximum number of simultaneously licensed users) 
and did not lead to any of this investigation's failures. The effectiveness of the Web page's electronic article retrieval devices (described in the "Procedures" section) would arguably approximate Kantor's "catalog branch" (can the item be located in the catalog?). Only one failure ( $0.6 \%$ the 173 total) - the instance in which more than 10 minutes was required for retrieval because access was not provided under the exact title-can be assigned to this branch. Library Operations (the item is not shelved correctly) does not have an obvious equivalent because electronic items are not shelved. The "patron" or "user" branch (a correctly shelved item cannot be located) does have an obvious electronic equivalent - the user's ability to retrieve an item-but was not examined here since this was a simulated study. However, the one instance of nonretrieval due to the investigator's searching error
( $0.6 \%$ of failures) could be viewed as a patron failure, although the percentage would presumably be higher in an investigation based on actual users. The four cases of failure to retrieve a theoretically available citation $(2.3 \%)$ (specifically the needed volume number could not be pulled up) appear to have been the fault of an external site to which the library linked and therefore do not readily fit into Kantor's framework, although they might be considered a type of "operations" failure. Finally, 1.7 percent (3) of the failures were due to a combination of reasons and thus cannot be attributed to a single branch.

An analysis of availability by language is illustrated in Table 3. It is striking that 72.5 percent (321 of 443) of the English language citations were available through the Library Web page, contrasted to only 10.5 percent (6 of 57) for citations in other languages. The science, profes-

\begin{tabular}{|c|c|c|c|c|c|}
\hline & Analysis & EA & $\begin{array}{l}3 \\
\text { ilability }\end{array}$ & anguage & \\
\hline Category & Number & & & Not & able \\
\hline & & Number & Percent & Number & Percent \\
\hline Area Studies & & & & & \\
\hline English & 68 & 48 & $70.6 \%$ & 20 & $29.4 \%$ \\
\hline Non-English & 32 & 3 & $9.4 \%$ & 29 & $90.6 \%$ \\
\hline Humanities & & & & & \\
\hline English & 81 & 44 & $54.3 \%$ & 37 & $45.7 \%$ \\
\hline Non-English & 19 & 1 & $5.3 \%$ & 18 & $94.7 \%$ \\
\hline Professional & lds & & & & \\
\hline English & 98 & 80 & $81.6 \%$ & 18 & $18.4 \%$ \\
\hline Non-English & 2 & 1 & $50 \%$ & 1 & $50 \%$ \\
\hline Sciences & & & & & \\
\hline English & 98 & 78 & $79.6 \%$ & 20 & $20.4 \%$ \\
\hline Non-English & 2 & 1 & $50 \%$ & 1 & $50 \%$ \\
\hline Social Scienc & & & & & \\
\hline English & 98 & 71 & $72.4 \%$ & 27 & $27.6 \%$ \\
\hline Non-English & 2 & 0 & $0 \%$ & 2 & $100 \%$ \\
\hline Grand Total & & & & & \\
\hline English & 443 & 321 & $72.5 \%$ & 122 & $27.5 \%$ \\
\hline Non-English & 57 & 6 & $10.5 \%$ & 51 & $89.5 \%$ \\
\hline
\end{tabular}


TABLE 4

Analysis of Electronic Availability by Publication Date and Category

\begin{tabular}{|l|c|c|c|c|c|c|}
\hline \hline \multirow{2}{*}{ Time Period* } & \multicolumn{2}{|c|}{ Number of Items } & \multicolumn{2}{c|}{ Available } & \multicolumn{2}{c|}{ Not Available } \\
\cline { 2 - 6 } & Number & Percent & Number & Percent & Number & Percent \\
\hline
\end{tabular}

\section{Area Studies}

\begin{tabular}{|l|c|c|c|c|c|c|}
\hline Before 1900 & 6 & $6 \%$ & 2 & $33.3 \%$ & 4 & $66.7 \%$ \\
\hline $1920 \mathrm{~s}$ & 2 & $2 \%$ & 0 & $0 \%$ & 2 & $100 \%$ \\
\hline $1930 \mathrm{~s}$ & 6 & $6 \%$ & 3 & $50 \%$ & 3 & $50 \%$ \\
\hline $1940 \mathrm{~s}$ & 2 & $2 \%$ & 1 & $50 \%$ & 1 & $50 \%$ \\
\hline $1950 \mathrm{~s}$ & 4 & $4 \%$ & 2 & $50 \%$ & 2 & $50 \%$ \\
\hline $1970 \mathrm{~s}$ & 8 & $8 \%$ & 2 & $25 \%$ & 6 & $75 \%$ \\
\hline $1980 \mathrm{~s}$ & 12 & $12 \%$ & 8 & $66.7 \%$ & 4 & $33.3 \%$ \\
\hline $1990 \mathrm{~s}$ & 24 & $24 \%$ & 12 & $50 \%$ & 12 & $50 \%$ \\
\hline $2000 \mathrm{~s}$ & 36 & $36 \%$ & 21 & $58.3 \%$ & 15 & $41.7 \%$ \\
\hline Total & $\mathbf{1 0 0}$ & $\mathbf{1 0 0} \%$ & $\mathbf{5 1}$ & $\mathbf{5 1 \%}$ & $\mathbf{4 9}$ & $\mathbf{4 9 \%}$ \\
\hline
\end{tabular}

\section{Humanities}

\begin{tabular}{|c|c|c|c|c|c|c|}
\hline Before 1900 & 2 & $2 \%$ & 0 & $0 \%$ & 2 & $100 \%$ \\
\hline 1900-1909 & 2 & $2 \%$ & 2 & $100 \%$ & 0 & $0 \%$ \\
\hline 1920 s & 1 & $1 \%$ & 0 & $0 \%$ & 1 & $100 \%$ \\
\hline $1930 \mathrm{~s}$ & 4 & $4 \%$ & 2 & $50 \%$ & 2 & $50 \%$ \\
\hline $1950 \mathrm{~s}$ & 5 & $5 \%$ & 2 & $40 \%$ & 3 & $60 \%$ \\
\hline $1960 \mathrm{~s}$ & 2 & $2 \%$ & 0 & $0 \%$ & 2 & $100 \%$ \\
\hline $1970 \mathrm{~s}$ & 12 & $12 \%$ & 6 & $50 \%$ & 6 & $50 \%$ \\
\hline $1980 \mathrm{~s}$ & 18 & $18 \%$ & 8 & $44.4 \%$ & 10 & $55.6 \%$ \\
\hline $1990 \mathrm{~s}$ & 24 & $24 \%$ & 10 & $41.7 \%$ & 14 & $58.3 \%$ \\
\hline $2000 \mathrm{~s}$ & 30 & $30 \%$ & 15 & $50 \%$ & 15 & $50 \%$ \\
\hline Total & 100 & $100 \%$ & 45 & $45 \%$ & 55 & $55 \%$ \\
\hline \multicolumn{7}{|c|}{ Professional Fields } \\
\hline $1960 \mathrm{~s}$ & 1 & $1 \%$ & 1 & $100 \%$ & 0 & $0 \%$ \\
\hline $1970 \mathrm{~s}$ & 2 & $2 \%$ & 1 & $50 \%$ & 1 & $50 \%$ \\
\hline $1980 \mathrm{~s}$ & 5 & $5 \%$ & 4 & $80 \%$ & 1 & $20 \%$ \\
\hline $1990 \mathrm{~s}$ & 39 & $39 \%$ & 34 & $87.2 \%$ & 5 & $12.8 \%$ \\
\hline $2000 \mathrm{~s}$ & 53 & $53 \%$ & 41 & $77.4 \%$ & 12 & $22.6 \%$ \\
\hline Total & 100 & $100 \%$ & 81 & $81 \%$ & 19 & $19 \%$ \\
\hline \multicolumn{7}{|l|}{ Sciences } \\
\hline $1930 \mathrm{~s}$ & 2 & $2 \%$ & 1 & $50 \%$ & 1 & $50 \%$ \\
\hline $1960 \mathrm{~s}$ & 1 & $1 \%$ & 1 & $100 \%$ & 0 & $0 \%$ \\
\hline $1970 \mathrm{~s}$ & 5 & $5 \%$ & 4 & $80 \%$ & 1 & $20 \%$ \\
\hline $1980 \mathrm{~s}$ & 10 & $10 \%$ & 6 & $60 \%$ & 4 & $40 \%$ \\
\hline $1990 \mathrm{~s}$ & 29 & $29 \%$ & 24 & $82.8 \%$ & 5 & $17.2 \%$ \\
\hline
\end{tabular}




\begin{tabular}{|c|c|c|c|c|c|c|}
\hline Analysis & Electron & Availal & $\begin{array}{l}\text { BLE } 4 \\
\text { by Publ }\end{array}$ & ion Date & and Cate & \\
\hline Time Period* & " Number & of Items & Avai & & Not Av & ailable \\
\hline & Number & Percent & Number & Percent & Number & Percent \\
\hline $2000 \mathrm{~s}$ & 53 & $53 \%$ & 43 & $81.1 \%$ & 10 & $18.9 \%$ \\
\hline Total & 100 & $100 \%$ & 79 & $79 \%$ & 21 & $21 \%$ \\
\hline Social Science & & & & & & \\
\hline Before 1900 & 2 & $2 \%$ & 0 & $0 \%$ & 2 & $100 \%$ \\
\hline 1900-1909 & 1 & $1 \%$ & 0 & $0 \%$ & 1 & $100 \%$ \\
\hline $1920 \mathrm{~s}$ & 2 & $2 \%$ & 0 & $0 \%$ & 2 & $100 \%$ \\
\hline $1960 \mathrm{~s}$ & 2 & $2 \%$ & 1 & $50 \%$ & 1 & $50 \%$ \\
\hline $1970 \mathrm{~s}$ & 4 & $4 \%$ & 2 & $50 \%$ & 2 & $50 \%$ \\
\hline $1980 \mathrm{~s}$ & 8 & $8 \%$ & 3 & $37.5 \%$ & 5 & $62.5 \%$ \\
\hline $1990 \mathrm{~s}$ & 44 & $44 \%$ & 31 & $70.5 \%$ & 13 & $29.5 \%$ \\
\hline $2000 \mathrm{~s}$ & 37 & $37 \%$ & 34 & $91.9 \%$ & 3 & $8.1 \%$ \\
\hline Total & 100 & $100 \%$ & 71 & $71 \%$ & 29 & $29 \%$ \\
\hline Grand Total & & & & & & \\
\hline Before 1900 & 10 & $2 \%$ & 2 & $20 \%$ & 8 & $80 \%$ \\
\hline 1900-1909 & 3 & $.6 \%$ & 2 & $66.7 \%$ & 1 & $33.3 \%$ \\
\hline $1920 \mathrm{~s}$ & 5 & $1 \%$ & 0 & $0 \%$ & 5 & $100 \%$ \\
\hline $1930 \mathrm{~s}$ & 12 & $2.4 \%$ & 6 & $50 \%$ & 6 & $50 \%$ \\
\hline $1940 \mathrm{~s}$ & 2 & $.4 \%$ & 1 & $50 \%$ & 1 & $50 \%$ \\
\hline $1950 \mathrm{~s}$ & 9 & $1.8 \%$ & 4 & $44.4 \%$ & 5 & $55.6 \%$ \\
\hline $1960 \mathrm{~s}$ & 6 & $1.2 \%$ & 3 & $50 \%$ & 3 & $50 \%$ \\
\hline $1970 \mathrm{~s}$ & 31 & $6.2 \%$ & 15 & $48.4 \%$ & 16 & $51.6 \%$ \\
\hline $1980 \mathrm{~s}$ & 53 & $10.6 \%$ & 29 & $54.7 \%$ & 24 & $45.3 \%$ \\
\hline $1990 \mathrm{~s}$ & 160 & $32 \%$ & 111 & $69.4 \%$ & 49 & $30.6 \%$ \\
\hline $2000 \mathrm{~s}$ & 209 & $41.8 \%$ & 154 & $73.7 \%$ & 55 & $26.3 \%$ \\
\hline Total & 500 & $100 \%$ & 327 & $65.4 \%$ & 173 & $34.6 \%$ \\
\hline
\end{tabular}

sional field, and social science citations were almost exclusively in English, while approximately one fifth of the humanities citations and one third of those in area studies were in languages other than English. The two categories with the highest proportion of non-English citations, humanities and area studies, displayed the lowest overall availability rates, but their language composition is only a partial explanation for the weaker performance. Although not indicated in table 3, eleven languages besides English were included in the 500-item sample. None of the following were available: 1 Dutch, 1 Hebrew, 1 Turkish, 3 Catalan, 3 Italian, and 4 Chinese citations. One of 2 Portuguese, 4 Spanish, 8 Russian, and 11 German citations were available. Finally, 2 of 19 French citations were available.

Table 4 summarizes availability by publication date and category. The "Grand Total" section clearly shows a positive association between citation cur- 
rency and availability through the library Web page. A linear relationship in which the availability rate declines with age is evident for the four most recent decades: 73.7 percent of items published during the 2000s; 69.4 percent of those published during the 1990s; 54.7 percent of citations from the 1980s; and 48.4 percent of those from the 1970s were available in full text. In contrast, only 20 percent of the items published before 1900 were available. Also, as would be expected, categories with more current citations tended to have higher availability rates. While 41.8 percent of all the citations were published in the 2000s, the figure was 53 percent in the two categories with the highest overall availability rates in table 1 - professional fields $(81 \%)$ and the sciences $(79 \%)$. The percentage published in the 2000s did not even reach 40 percent in any other category: social sciences $(37 \%)$, area studies $(36 \%)$, and the humanities (30\%).

Table 5 analyzes the simulated sample according to the Library of Congress class number for the cited journal, as indicated in WorldCat. Remember that the five broad categories analyzed in this paper are based on the source journals, not the cited journals. Three of the cited titles were not found in WorldCat, while 11 of those found in WorldCat (counted in the table as "Other") used a different classification system, such as the National Library of Medicine, or otherwise lacked an LC classification number.

Although ancillary to the primary research question, table 5 illustrates the interdisciplinary nature of contemporary scholarship - a well-known phenomenon supported by hundreds of citation studies. One can see that 16 LC classes are represented in area studies with the most prevalent, D (old world history), accounting for only 25 percent of the total. A similar pattern appears for the humanities (10 LC classes, with the largest accounting for only $25 \%$ ), professional fields (11 classes, with the largest producing only $27 \%$ ), and the social sciences (15 LC classes, with the largest contributing only $27 \%$ ).
In contrast, the sciences displayed low interdisciplinarity (only four classes were represented) and high concentration in one class ( $Q$ - the class for science itself), which accounted for 80 percent of the citations in science source journals. Overall, 19 of 21 LC classes were included in the total 500-item sample, with U (Military Science) and V (Naval Science) the two exceptions.

Discounting S (Agriculture), in which there were only two items, the highest electronic availability rate- 90 percentwas found in classes E (U.S. History) and $\mathrm{K}$ (Law). The availability rate exceeded 80 percent in three other LC classes: M (Music and Books on Music)-85.7\%; Z (Bibliography, Library Science, and General Information Resources) - $84.6 \%$; and J (Political Science) $-83.9 \%$, although there were only seven citations in $\mathrm{M}$. Three other classes had availability rates above 70 percent: $\mathrm{H}$ (Social Sciences) $-79.5 \%$; Q (Science)-74.2\%; and L (Education) $-71.4 \%$ (although the rate for $\mathrm{L}$, as with $\mathrm{M}$, is based on a less than robust dataset). Two traditional humanities classes that were well represented in the sample had availability rates considerably below the 65.4 percent total figure: $\mathrm{D}$ (History of Europe, Asia, Africa, Australia, New Zealand, etc.) at 42.5 percent and $\mathrm{P}$ (Language and Literature) at 46.8 percent.

While this investigation focused on electronic availability through the library Web page, holdings on the Bloomington campus in print and microform were also analyzed and the findings summarized in table 6. It is noteworthy that a somewhat larger proportion of the sample (73\%) was held in print than was available electronically $(65.4 \%)$. Items available electronically were more likely to be held in print than unavailable items $(83.5 \%$ contrasted to $53.2 \%$ ), suggesting that the latter group may have contained more marginal material. A similar pattern can be observed for microform (combining film and fiche) in which 7.3 percent of available items but only 4.6 percent of nonavailable ones were held in the format. Note that 16 items 


\begin{tabular}{|c|c|c|c|c|c|c|}
\hline & nalysis o & $\begin{array}{r}\text { lectronic } \\
\text { Clas }\end{array}$ & $\begin{array}{l}\text { TABLE } 5 \\
\text { ailability } \\
\text { cation N }\end{array}$ & $\begin{array}{l}\text { y Librar } \\
\text { aber }\end{array}$ & of Congr & \\
\hline Category & Numb & of Items & Ava & ble & Not & ilable \\
\hline & Number & Percent & Number & Percent & Number & Percent \\
\hline Area Studie & & & & & & \\
\hline A & 5 & $5 \%$ & 4 & $80 \%$ & 1 & $20 \%$ \\
\hline $\mathrm{B}$ & 5 & $5 \%$ & 2 & $40 \%$ & 3 & $60 \%$ \\
\hline $\mathrm{C}$ & 2 & $2 \%$ & 0 & $0 \%$ & 2 & $100 \%$ \\
\hline $\mathrm{D}$ & 25 & $25 \%$ & 12 & $48 \%$ & 13 & $52 \%$ \\
\hline $\mathrm{E}$ & 6 & $6 \%$ & 6 & $100 \%$ & 0 & $0 \%$ \\
\hline $\mathrm{F}$ & 2 & $2 \%$ & 1 & $50 \%$ & 1 & $50 \%$ \\
\hline G & 3 & $3 \%$ & 2 & $66.7 \%$ & 1 & $33.3 \%$ \\
\hline $\mathrm{H}$ & 17 & $17 \%$ & 11 & $64.7 \%$ & 6 & $35.3 \%$ \\
\hline $\mathrm{J}$ & 5 & $5 \%$ & 3 & $60 \%$ & 2 & $40 \%$ \\
\hline $\mathrm{K}$ & 1 & $1 \%$ & 1 & $100 \%$ & 0 & $0 \%$ \\
\hline $\mathrm{L}$ & 2 & $2 \%$ & 1 & $50 \%$ & 1 & $50 \%$ \\
\hline $\mathrm{N}$ & 1 & $1 \%$ & 1 & $100 \%$ & 0 & $0 \%$ \\
\hline $\mathrm{P}$ & 7 & $7 \%$ & 2 & $28.6 \%$ & 5 & $71.4 \%$ \\
\hline Q & 6 & $6 \%$ & 1 & $16.7 \%$ & 5 & $83.3 \%$ \\
\hline $\mathrm{R}$ & 1 & $1 \%$ & 1 & $100 \%$ & 0 & $0 \%$ \\
\hline $\mathrm{S}$ & 1 & $1 \%$ & 1 & $100 \%$ & 0 & $0 \%$ \\
\hline Newspaper & 9 & $9 \%$ & 2 & $22.2 \%$ & 7 & $77.8 \%$ \\
\hline Not Found & 1 & $1 \%$ & 0 & $0 \%$ & 1 & $100 \%$ \\
\hline Other & 1 & $1 \%$ & 0 & $0 \%$ & 1 & $100 \%$ \\
\hline Total & 100 & $100 \%$ & 51 & $51 \%$ & 49 & $49 \%$ \\
\hline Humanities & & & & & & \\
\hline A & 11 & $11 \%$ & 4 & $36.4 \%$ & 7 & $63.6 \%$ \\
\hline B & 17 & $17 \%$ & 10 & $58.8 \%$ & 7 & $41.2 \%$ \\
\hline $\mathrm{C}$ & 1 & $1 \%$ & 0 & $0 \%$ & 1 & $100 \%$ \\
\hline $\mathrm{D}$ & 9 & $9 \%$ & 1 & $11.1 \%$ & 8 & $88.9 \%$ \\
\hline $\mathrm{E}$ & 1 & $1 \%$ & 0 & $0 \%$ & 1 & $100 \%$ \\
\hline G & 12 & $12 \%$ & 6 & $50 \%$ & 6 & $50 \%$ \\
\hline $\mathrm{H}$ & 2 & $2 \%$ & 1 & $50 \%$ & 1 & $50 \%$ \\
\hline $\mathrm{M}$ & 7 & $7 \%$ & 6 & $85.7 \%$ & 1 & $14.3 \%$ \\
\hline $\mathrm{N}$ & 9 & $9 \%$ & 1 & $11.1 \%$ & 8 & $88.9 \%$ \\
\hline $\mathrm{P}$ & 25 & $25 \%$ & 12 & $48 \%$ & 13 & $52 \%$ \\
\hline Newspaper & 4 & $4 \%$ & 4 & $100 \%$ & 0 & $0 \%$ \\
\hline Not Found & 1 & $1 \%$ & 0 & $0 \%$ & 1 & $100 \%$ \\
\hline Other & 1 & $1 \%$ & 0 & $0 \%$ & 1 & $100 \%$ \\
\hline
\end{tabular}


TABLE 5

Analysis of Electronic Availability by Library of Congress Classification Number

\begin{tabular}{|l|c|c|c|c|c|c|}
\hline \multirow{2}{*}{ Category } & \multicolumn{2}{|c|}{ Number of Items } & \multicolumn{2}{c|}{ Available } & \multicolumn{2}{c|}{ Not Available } \\
\cline { 2 - 7 } & Number & Percent & Number & Percent & Number & Percent \\
\hline Total & 100 & $100 \%$ & 45 & $45 \%$ & 55 & $55 \%$ \\
\hline
\end{tabular}

Professional Fields

\begin{tabular}{|l|c|c|c|c|c|c|}
\hline $\mathrm{A}$ & 1 & $1 \%$ & 0 & $0 \%$ & 1 & $100 \%$ \\
\hline $\mathrm{B}$ & 4 & $4 \%$ & 4 & $100 \%$ & 0 & $0 \%$ \\
\hline $\mathrm{D}$ & 2 & $2 \%$ & 2 & $100 \%$ & 0 & $0 \%$ \\
\hline $\mathrm{H}$ & 27 & $27 \%$ & 24 & $88.9 \%$ & 3 & $11.1 \%$ \\
\hline $\mathrm{J}$ & 10 & $10 \%$ & 8 & $80 \%$ & 2 & $20 \%$ \\
\hline $\mathrm{K}$ & 8 & $8 \%$ & 7 & $87.5 \%$ & 1 & $12.5 \%$ \\
\hline $\mathrm{L}$ & 5 & $5 \%$ & 4 & $80 \%$ & 1 & $20 \%$ \\
\hline $\mathrm{P}$ & 2 & $2 \%$ & 2 & $100 \%$ & 0 & $0 \%$ \\
\hline $\mathrm{Q}$ & 5 & $5 \%$ & 5 & $100 \%$ & 0 & $0 \%$ \\
\hline $\mathrm{R}$ & 19 & $19 \%$ & 13 & $68.4 \%$ & 6 & $31.6 \%$ \\
\hline $\mathrm{Z}$ & 10 & $10 \%$ & 8 & $80 \%$ & 2 & $20 \%$ \\
\hline Newspaper & 1 & $1 \%$ & 1 & $100 \%$ & 0 & $0 \%$ \\
\hline Other & 6 & $6 \%$ & 3 & $50 \%$ & 3 & $50 \%$ \\
\hline Total & $\mathbf{1 0 0}$ & $\mathbf{1 0 0} \%$ & $\mathbf{8 1}$ & $\mathbf{8 1 \%}$ & $\mathbf{1 9}$ & $\mathbf{1 9 \%}$ \\
\hline Sciences & & & & & & \\
\hline
\end{tabular}

Sciences

\begin{tabular}{|l|c|c|c|c|c|c|}
\hline $\mathrm{Q}$ & 80 & $80 \%$ & 63 & $78.8 \%$ & 17 & $21.2 \%$ \\
\hline $\mathrm{R}$ & 3 & $3 \%$ & 3 & $100 \%$ & 0 & $0 \%$ \\
\hline $\mathrm{T}$ & 11 & $11 \%$ & 7 & $63.6 \%$ & 4 & $36.4 \%$ \\
\hline $\mathrm{Z}$ & 3 & $3 \%$ & 3 & $100 \%$ & 0 & $0 \%$ \\
\hline Not Found & 1 & $1 \%$ & 1 & $100 \%$ & 0 & $0 \%$ \\
\hline Other & 2 & $2 \%$ & 2 & $100 \%$ & 0 & $0 \%$ \\
\hline Total & $\mathbf{1 0 0}$ & $\mathbf{1 0 0} \%$ & $\mathbf{7 9}$ & $\mathbf{7 9 \%}$ & $\mathbf{2 1}$ & $\mathbf{2 1 \%}$ \\
\hline
\end{tabular}

\section{Social Sciences}

\begin{tabular}{|l|c|c|c|c|c|c|}
\hline $\mathrm{A}$ & 1 & $1 \%$ & 1 & $100 \%$ & 0 & $0 \%$ \\
\hline $\mathrm{B}$ & 5 & $5 \%$ & 5 & $100 \%$ & 0 & $0 \%$ \\
\hline $\mathrm{D}$ & 4 & $4 \%$ & 2 & $50 \%$ & 2 & $50 \%$ \\
\hline $\mathrm{E}$ & 3 & $3 \%$ & 3 & $100 \%$ & 0 & $0 \%$ \\
\hline $\mathrm{F}$ & 1 & $1 \%$ & 1 & $100 \%$ & 0 & $0 \%$ \\
\hline $\mathrm{G}$ & 6 & $6 \%$ & 3 & $50 \%$ & 3 & $50 \%$ \\
\hline $\mathrm{H}$ & 27 & $27 \%$ & 22 & $81.5 \%$ & 5 & $18.5 \%$ \\
\hline $\mathrm{J}$ & 16 & $16 \%$ & 15 & $93.8 \%$ & 1 & $6.2 \%$ \\
\hline $\mathrm{K}$ & 1 & $1 \%$ & 1 & $100 \%$ & 0 & $0 \%$ \\
\hline $\mathrm{N}$ & 1 & $1 \%$ & 1 & $100 \%$ & 0 & $0 \%$ \\
\hline
\end{tabular}




\begin{tabular}{|c|c|c|c|c|c|c|}
\hline & nalysis o & $\begin{array}{r}\text { lectronic } \\
\text { Clas }\end{array}$ & $\begin{array}{l}\text { ГABLE } 5 \\
\text { ailability } \\
\text { cation N }\end{array}$ & $\begin{array}{l}\text { y Librar } \\
\text { aber }\end{array}$ & of Congr & \\
\hline Category & Numb & of Items & Ava & ble & Not $A$ & ilable \\
\hline & Number & Percent & Number & Percent & Number & Percent \\
\hline $\mathrm{P}$ & 13 & $13 \%$ & 6 & $46.2 \%$ & 7 & $53.8 \%$ \\
\hline Q & 6 & $6 \%$ & 3 & $50 \%$ & 3 & $50 \%$ \\
\hline $\mathrm{R}$ & 11 & $11 \%$ & 5 & $45.5 \%$ & 6 & $54.5 \%$ \\
\hline $\mathrm{S}$ & 1 & $1 \%$ & 1 & $100 \%$ & 0 & $0 \%$ \\
\hline $\mathrm{T}$ & 1 & $1 \%$ & 1 & $100 \%$ & 0 & $0 \%$ \\
\hline Newspaper & 2 & $2 \%$ & 1 & $50 \%$ & 1 & $50 \%$ \\
\hline Other & 1 & $1 \%$ & 0 & $0 \%$ & 1 & $100 \%$ \\
\hline Total & 100 & $100 \%$ & 71 & $71 \%$ & 29 & $29 \%$ \\
\hline Grand Tot & & & & & & \\
\hline $\mathrm{A}$ & 18 & $3.6 \%$ & 9 & $50 \%$ & 9 & $50 \%$ \\
\hline B & 31 & $6.2 \%$ & 21 & $67.7 \%$ & 10 & $32.3 \%$ \\
\hline $\mathrm{C}$ & 3 & $.6 \%$ & 0 & $0 \%$ & 3 & $100 \%$ \\
\hline $\mathrm{D}$ & 40 & $8 \%$ & 17 & $42.5 \%$ & 23 & $57.5 \%$ \\
\hline $\mathrm{E}$ & 10 & $2 \%$ & 9 & $90 \%$ & 1 & $10 \%$ \\
\hline $\mathrm{F}$ & 3 & $.6 \%$ & 2 & $66.7 \%$ & 1 & $33.3 \%$ \\
\hline G & 21 & $4.2 \%$ & 11 & $52.4 \%$ & 10 & $47.6 \%$ \\
\hline $\mathrm{H}$ & 73 & $14.6 \%$ & 58 & $79.5 \%$ & 15 & $20.5 \%$ \\
\hline $\mathrm{J}$ & 31 & $6.2 \%$ & 26 & $83.9 \%$ & 5 & $16.1 \%$ \\
\hline $\mathrm{K}$ & 10 & $2 \%$ & 9 & $90 \%$ & 1 & $10 \%$ \\
\hline $\mathrm{L}$ & 7 & $1.4 \%$ & 5 & $71.4 \%$ & 2 & $28.6 \%$ \\
\hline$M$ & 7 & $1.4 \%$ & 6 & $85.7 \%$ & 1 & $14.3 \%$ \\
\hline $\mathrm{N}$ & 11 & $2.2 \%$ & 3 & $27.3 \%$ & 8 & $72.7 \%$ \\
\hline $\mathrm{P}$ & 47 & $9.4 \%$ & 22 & $46.8 \%$ & 25 & $53.2 \%$ \\
\hline $\mathrm{Q}$ & 97 & $19.4 \%$ & 72 & $74.2 \%$ & 25 & $25.8 \%$ \\
\hline $\mathrm{R}$ & 34 & $6.8 \%$ & 22 & $64.7 \%$ & 12 & $35.3 \%$ \\
\hline$S$ & 2 & $.4 \%$ & 2 & $100 \%$ & 0 & $0 \%$ \\
\hline $\mathrm{T}$ & 12 & $2.4 \%$ & 8 & $66.7 \%$ & 4 & $33.3 \%$ \\
\hline $\mathrm{Z}$ & 13 & $2.6 \%$ & 11 & $84.6 \%$ & 2 & $15.4 \%$ \\
\hline Newspaper & 16 & $3.2 \%$ & 8 & $50 \%$ & 8 & $50 \%$ \\
\hline Not Found & 3 & $.6 \%$ & 1 & $33.3 \%$ & 2 & $66.7 \%$ \\
\hline Other & 11 & $2.2 \%$ & 5 & $45.5 \%$ & 6 & $54.5 \%$ \\
\hline Total & 500 & $100 \%$ & 327 & $65.4 \%$ & 173 & $34.6 \%$ \\
\hline
\end{tabular}




\begin{tabular}{|c|c|c|c|c|c|c|c|c|c|}
\hline & & & Analy & $\begin{array}{l}A B L \\
\text { is by }\end{array}$ & $\begin{array}{l}6 \\
\text { Format }\end{array}$ & & & & \\
\hline Category & Number & & $\begin{array}{l}\text { Id in } \\
\text { rint }\end{array}$ & $\begin{array}{r}\mathbf{F} \\
\text { Mic }\end{array}$ & $\begin{array}{l}\text { ld in } \\
\text { format }\end{array}$ & $\begin{array}{r}\text { Held } \\
\text { Mic }\end{array}$ & $\begin{array}{l}\text { Print or } \\
\text { ormat }\end{array}$ & $\begin{array}{r}\text { Helc } \\
\text { F }\end{array}$ & $\begin{array}{l}\text { in Any } \\
\text { rmat }\end{array}$ \\
\hline & & No. & $\%$ & No. & $\%$ & No. & $\%$ & No. & $\%$ \\
\hline Area Studies & & & & & & & & & \\
\hline $\begin{array}{l}\text { Available } \\
\text { Electronically }\end{array}$ & 51 & 45 & $88.2 \%$ & 5 & $9.8 \%$ & 47 & $92.2 \%$ & 51 & $100 \%$ \\
\hline $\begin{array}{l}\text { Not Available } \\
\text { Electronically }\end{array}$ & 49 & 21 & $42.9 \%$ & 4 & $8.2 \%$ & 25 & $51 \%$ & 25 & $51 \%$ \\
\hline Total & 100 & 66 & $66 \%$ & 9 & $9 \%$ & 72 & $72 \%$ & 76 & $76 \%$ \\
\hline Humanities & & & & & & & & & \\
\hline $\begin{array}{l}\text { Available } \\
\text { Electronically }\end{array}$ & 45 & 32 & $71.1 \%$ & 5 & $11.1 \%$ & 35 & $77.8 \%$ & 45 & $100 \%$ \\
\hline $\begin{array}{l}\text { Not Available } \\
\text { Electronically }\end{array}$ & 55 & 31 & $56.4 \%$ & 2 & $3.6 \%$ & 33 & $60 \%$ & 33 & $60 \%$ \\
\hline Total & 100 & 63 & $63 \%$ & 7 & $7 \%$ & 68 & $68 \%$ & 78 & $78 \%$ \\
\hline Professional F & elds & & & & & & & & \\
\hline $\begin{array}{l}\text { Available } \\
\text { Electronically }\end{array}$ & 81 & 68 & $84 \%$ & 5 & $6.2 \%$ & 69 & $85.2 \%$ & 81 & $100 \%$ \\
\hline $\begin{array}{l}\text { Not Available } \\
\text { Electronically }\end{array}$ & 19 & 7 & $36.8 \%$ & 1 & $5.3 \%$ & 8 & $42.1 \%$ & 8 & $42.1 \%$ \\
\hline Total & 100 & 75 & $75 \%$ & 6 & $6 \%$ & 77 & $77 \%$ & 89 & $89 \%$ \\
\hline Sciences & & & & & & & & & \\
\hline $\begin{array}{l}\text { Available } \\
\text { Electronically }\end{array}$ & 79 & 67 & $84.8 \%$ & 2 & $2.5 \%$ & 67 & $84.8 \%$ & 79 & $100 \%$ \\
\hline $\begin{array}{l}\text { Not Available } \\
\text { Electronically }\end{array}$ & 21 & 13 & $61.9 \%$ & 0 & $0 \%$ & 13 & $61.9 \%$ & 13 & $61.9 \%$ \\
\hline Total & 100 & 80 & $80 \%$ & 2 & $2 \%$ & 80 & $80 \%$ & 92 & $92 \%$ \\
\hline Social Science & & & & & & & & & \\
\hline $\begin{array}{l}\text { Available } \\
\text { Electronically }\end{array}$ & 71 & 61 & $85.9 \%$ & 7 & $9.9 \%$ & 63 & $88.7 \%$ & 71 & $100 \%$ \\
\hline $\begin{array}{l}\text { Not Available } \\
\text { Electronically }\end{array}$ & 29 & 20 & $69 \%$ & 1 & $3.4 \%$ & 21 & $72.4 \%$ & 21 & $72.4 \%$ \\
\hline Total & 100 & 81 & $81 \%$ & 8 & $8 \%$ & 84 & $84 \%$ & 92 & $92 \%$ \\
\hline Grand Total & & & & & & & & & \\
\hline $\begin{array}{l}\text { Available } \\
\text { Electronically }\end{array}$ & 327 & 273 & $83.5 \%$ & 24 & $7.3 \%$ & 281 & $85.9 \%$ & 327 & $100 \%$ \\
\hline $\begin{array}{l}\text { Not Available } \\
\text { Electronically }\end{array}$ & 173 & 92 & $53.2 \%$ & 8 & $4.6 \%$ & 100 & $57.8 \%$ & 100 & $57.8 \%$ \\
\hline Total & 500 & 365 & $73 \%$ & 32 & $6.4 \%$ & 381 & $76.2 \%$ & 427 & $85.4 \%$ \\
\hline
\end{tabular}


were available and held in three different formats: print, microform, and electronic. Finally, because 100 of the electronically unavailable items $(57.8 \%)$ were held in either print or microform, 427 of the 500item sample $(85.4 \%)$ should have been obtainable on the Bloomington campus. Although unsurprising, this finding does demonstrate that electronic and traditional (that is, print and microform) resources are stronger in combination than either one by itself.

Of the 92 nonavailable items held in print, $21(22.8 \%)$ items were in remote storage (the Auxiliary Library Facility or ALF) and definitely would not have been immediately available to patrons. (One must request an item before noon to receive it by 5 P.M. ${ }^{51}$ ) Note that 91 (33.3\%) of the 273 items both available electronically and held in print were in remote storage, although it is questionable how often patrons would seek the print version of an electronically available document. In total, 30.7 percent (112 of 365 ) of the print-held items were in the ALF and thus not immediately available. No attempt was made to determine the actual shelf availability of the remaining print or microform items. While these formats usually do not circulate in the IUBloomington library system, the required volume or issue could have been in use by a patron or misshelved.

\section{Comparison of Results with Other Availability Studies}

After data from an evaluation project are tabulated and analyzed, a fundamental issue remains: interpretation of the results. What score should one expect? Although no other investigation of availability found in the literature review is identical to this one, a review of the results from other availability studies provides some context for assessing the results found here. Compared to real (that is, patron based), known-item availability studies for mostly print resources, this investigation's 65.4 percent electronic availability rate is somewhat higher than the average rates found by both Mansbridge (61\% for 26 studies) ) $^{52}$ and Nisonger (a 61.3\% unweighted average or a $63.1 \%$ weighted average for 46 investigations). ${ }^{53}$ More specifically, 65.4 percent availability is higher than 18 of Mansbridge's data points, lower than 7 and essentially tied with one. Unfortunately, Mansbridge does not report the average availability rate or specific results from simulated investigations. ${ }^{54}$ In the Nisonger literature review, the availability rates ranged from 33.8 percent to 83.8 percent in user-based studies. This article's results were higher than 27 of these investigations, but lower than 19 . Nisonger also found that the unweighted mean availability rate for 8 simulated investigations was 61.8 percent and the weighted mean 60.6 percent, with the specific results ranging from 13.0 percent to 84.0 percent. If the 13.0 percent score, which could be considered an outlier, is disregarded, availability rises to an unweighted mean of 68.8 percent and a weighted mean of 69.1 percent. Five of the eight simulated studies in Nisonger's review resulted in higher availability rates than the one found here, ${ }^{55}$ including a 69.4 percent rate in the University of Cape Town Medical Library for journal articles published by South African biomedical researchers. ${ }^{56}$

Compared to availability rates for print journal or serial articles in real studies, these results were considerably lower than the 80.9 percent rate found at the University of North Carolina Chapel Hill Health Sciences Library, ${ }^{57}$ but higher than 58.6 percent at King Fahd University of Petroleum and Minerals, ${ }^{58} 56$ percent at the University of New Mexico, 5955 percent at East Tennessee State University, ${ }^{60}$ 54 percent at the University of Western Australia, ${ }^{61}$ and 44.9 percent at Adelphi University. ${ }^{62}$

More direct comparisons can be made with studies investigating the electronic availability of journal citations through library Web pages. Schaffer discovered that "less than one-third" of the journal articles cited by Texas A \& M psychol- 
ogy faculty were available in full text in at least one of 26 electronic databases licensed by the university library ${ }^{63}-$ equally approximately half the 65.4 percent rate found here and even less than the 71 percent availability rate for the social sciences. In contrast, the 81 percent electronic availability rate for journal articles cited by Claremont Colleges biology faculty in Price's investigation ${ }^{64}$ and the 78 percent rate reported by Squires, Moore, and Keesee for the health sciences at the University of North Carolina at Chapel Hill ${ }^{65}$ are remarkably close to the 79 percent rate for the sciences and 81 percent for professional field (health sciences can be legitimately compared to both the sciences and professional fields) found here. Preliminary data from an unpublished investigation of the electronic availability of citations from social science faculty publications at the University of Illinois at Chicago by Stephen E. Wiberley, Jr. show a 78.4 percent rate (69 of 88) for journals, somewhat higher than this study's result for the social sciences. Note that Wiberley's overall availability rate was 45.3 percent (72 of 159) when all formats are considered. ${ }^{66}$ In summary, this investigation's overall availability rate is somewhat higher than for most studies of print materials, but not enough comparable studies of electronic availability were identified to allow generalizations. In fact, no other identified study was precisely comparable with this one.

\section{Limitations to the Study}

The fact that this was a simulated study that did not incorporate real users is undoubtedly the biggest limitation. A number of other limitations must be acknowledged. The investigator searched in his office (which is hardwired for high-speed access) rather than on his home computer, where response time is slower; it is possible that Indiana University users searching from a remote location without high-speed Internet access would obtain poorer results because some items were not retrieved within the 10-minute limit. The focus is on research rather than teaching needs. Since it is a simulated study, the results indicate potential rather than actual availability. Formats other than serials have not been included in the simulated methodology. A different set of sample parameters might have produced somewhat different findings. Since the data were gathered, the Web page for the Indiana University Bloomington libraries has been redesigned and it is unknown how or if this impacts availability.

\section{Conclusions}

This research project demonstrates once again that traditional collection evaluation or library performance measures developed for a print environment can be modified for application to electronic resources or a hybrid library. More specifically, the availability study method has been adapted to test near-immediate full-text retrieval on a terminal screen rather than location of an item on a library shelf, while the followup analysis of print holdings incorporates the approach of a citation-based checklist. This investigation differs from the other electronic availability studies reviewed here because: it is based on a simulated sample rather than citations from library clients; 50 subject areas rather than one serve as the source for the citations; and the results are compared with those from availability studies for print resources.

The investigation's conclusions may be summarized as follows:

- the simulated electronic availability rate for serial citations appears to be slightly higher than the overall average rates found in patron-based availability studies for print materials and for most patron-based investigations of print serial availability;

- as the literature review did not locate a single electronic availability study that incorporated actual searching by patrons, the results that would be obtained by a "real" electronic availability study are unknown; 
- the so-called "hybrid library," combining electronic and print resources, meets a larger proportion of simulated user need than would an all-electronic or an all-print collection - at least as of mid 2007;

- electronic availability varies widely according to the sought-after item's subject, age, and language;

- as the continuing need (as indicated by citations in scholarly literature) for older and non-English material is confirmed, research libraries should either expand their licensing for these parameters (if provided by vendors) or maintain print collections;

- modification of Kantor's branching method for an electronic environment indicates that the "acquisitions barrier" - the needed item was not licensed or linked to-is the primary cause of nonavailability.
Strategies for future research investigating electronic availability include:

- a "real" study incorporating actual users (for which a lower availability rate might be expected due to user error);

- a thorough investigation of thirdparty failure as a barrier to availability;

- implementation of the identical simulated methodology at future yearly intervals on the Indiana University Bloomington library Web page for longitudinal comparison;

- implementation of a similar simulated methodology on the Web pages of other large research libraries for crosssectional comparison;

- use of a simulated investigation, based on a sample created to represent teaching rather than research needs;

- use of log transaction analysis; and

- various permutations on the strategies outlined above.

\section{Notes}

1. Lynn B. Chandler, "Book Availability in the Cameron Village Regional Library," (Master's paper, University of North Carolina at Chapel Hill, 1998), 2.

2. F.W. Lancaster, If You Want to Evaluate Your Library. . . (Champaign, Ill.: University of Illinois, Graduate School of Library and Information Science, 1993), 12, who cites Ranganathan's Second Law of Library Science, "Every Reader His Book."

3. Gene E. Rinkel and Patricia McCandless, "Application of a Methodology Analyzing User Frustration," College \& Research Libraries 44 (Jan. 1983): 29-37.

4. This is an approximate quotation, based on the author's memory, from Herbert S. White's presentation at the Indiana University School of Library and Information Science on May 9, 2003.

5. Paul B. Kantor, "Availability Analysis," Journal of the American Society for Information Science 27 (Sept.-Oct. 1976): 311-19.

6. Judith B.Wood, Julius J. Bremer, and Susan A. Saraidaridis, "Measurement of Service at a Public Library," Public Library Quarterly 2 (summer 1980): 49-57.

7. Faraj Mohamed Kuraim, "The Principal Factors Causing Reader Frustration in a Public Library" (Ph.D. diss., Case Western Reserve University, 1983).

8. Neal K. Kaske, "Materials Availability Model and the Internet," Journal of Academic Librarianship 20 (Nov. 1994): 317-18.

9. Thomas E. Nisonger, "A Review and Analysis of Library Availability Studies," Library Resources \& Technical Services 51 (Jan. 2007): 36.

10. H.V. Gaskill, R.M. Dunbar, and C.H. Brown, "An Analytical Study of the Use of a College Library," Library Quarterly 4 (Oct. 1934): 564-87.

11. John Mansbridge, "Availability Studies in Libraries," Library \& Information Science Research 8 (Oct.-Dec. 1986): 299-314.

12. Ibid., 300.

13. Nisonger, "A Review and Analysis of Library Availability Studies," 33.

14. Ibid.

15. Lindiwe E. Zondi, "Measuring Availability and Non-availability Rates at the University of Zululand Library," South African Journal of Library \& Information Science 64 (June 1996): 108-13.

16. Sajjad Ur Rehman, Kokab Arif, and Abdous Sattar Chaudhry, "Availability Analysis: Conduct, Comparison and Applications," Australian Academic \& Research Libraries 25 (Mar. 1994): $19-26$. 
17. Julia Shaw-Kokot and Claire de la Varre, "Using a Journal Availability Study to Improve Access," Bulletin of the Medical Library Association 89 (Jan. 2001): 21-28.

18. Anne Ciliberti et al., "Empty Handed? A Material Availability Study and Transaction Log Analysis Verification," Journal of Academic Librarianship 24 (July 1998): 284.

19. Abdus Sattar Chaudhry and Saleh Ashoor, "Comprehensive Materials Availability Studies in Academic Libraries," Journal of Academic Librarianship 20 (Nov. 1994): 300-05.

20. Melanie Harris and Imogen Garner, "Using an Availability Survey to Improve Service at a University Library," Australian Academic \& Research Libraries 23 (Mar. 1992): 25-34.

21. Jan Bachmann-Derthick and Sandra Spurlock, "Journal Availability at the University of New Mexico," in Advances in Serials Management, vol. 3, eds. Jean G. Cook and Marcia Tuttle (Greenwich, Conn.: JAI Press, 1989), 173-212.

22. Jennifer Eugenie Roberts, "Journal Availability Study" (Master's paper, University of North Carolina at Chapel Hill, 1989).

23. Roger Edward Stelk and F.W. Lancaster, "The Use of Shelflist Samples in Studies of Book Availability," Collection Management 13, no. 4 (1990): 19-24.

24. Chaudhry and Ashoor, "Comprehensive Materials Availability Studies in Academic Libraries."

25. Susan Steynberg and S.F. Rossouw, "The Availability of Research Journals in South African Academic Medical Libraries," South African Medical Journal 83 (Nov. 1993): 837-39.

26. Guide to the Evaluation of Library Collections, ed. Barbara Lockett (Chicago: American Library Association, 1989), 5-6.

27. C.C. Jewett, "Report of the Assistant Secretary Relative to the Library, Presented December 13, 1848," in Third Annual Report of the Board of Regents of the Smithsonian Institution to the Senate and House of Representatives (Washington, D.C.: Tippin and Streeper, 1849): 39-47.

28. William L. Emerson, "Adequacy of Engineering Resources for Doctoral Research in a University Library," College E Research Libraries 18 (Nov. 1957): 455-60, 504.

29. Thomas E. Nisonger, "A Test of Two Citation Checking Techniques for Evaluating Political Science Collections in University Libraries," Library Resources \& Technical Services 27 (Apr./June 1983): 163-76.

30. Reba Leiding, "Using Citation Checking of Undergraduate Honors Thesis Bibliographies to Evaluate Library Collections," College E Research Libraries 66 (Sept. 2005): 417-29.

31. Thomas E. Nisonger, "Use of the Checklist Method for Content Evaluation of Full Text Databases: An Investigation of Two Databases Based on Citations from Two Journals," Library Resources \& Technical Services 52 (Jan. 2008): 4-17.

32. David C. Tyler, Signe O. Boudreau, and Susan M. Leach, "The Communication Studies Researcher and the Communication Studies Indexes," Behavioral E Social Sciences Librarian 23, no. 2 (2005): 119-46.

33. Nisonger, "Use of the Checklist Method for Content Evaluation of Full Text Databases."

34. Thomas Schaffer, "Psychology Citations Revisited: Behavioral Research in the Age of Electronic Resources," Journal of Academic Librarianship 30 (Sept. 2004): 354-60.

35. Jason S. Price, "How Many Journals Do We Have? An Alternative Approach to Journal Collection Evaluation Through Local Cited Article Analysis," Serials 20 (July 2007): 134-41.

36. Steven J. Squires, Margaret E. Moore, and Susan H. Keesee, "Electronic Journal Availability Study." Available online at www.eblip4.unc.edu/papers/Squires.pdf. [Accessed 23 May 2008].

37. Bradley Brazzeal and Amanda Clay Powers, "Electronic Access to Agricultural Journals: An Agronomy Case Study," Serials Review (Sept. 2007): 155-60.

38. Kathleen E. Joswick, "Full Text Psychology Journals Available from Popular Library Databases," Journal of Academic Librarianship 32 (2006): 349-54.

39. Dana M. Caudle and Cecilia M. Schmitz, "Web Access to Electronic Journals with Databases in ARL Libraries," Journal of Web Librarianship 1, no. 1 (2007): 3-26.

40. Wikipedia, "Indiana University (Bloomington)." Available online at http://en.wikipedia. org/wiki/Indiana_University_\%28Bloomingto. [Accessed 29 November 2007].

41. Indiana University, Indiana University Fact Book 2007-08 (Bloomington, Ind.: Indiana University, University Reporting and Research, 2008), 2. Available online at http://factbook.indiana. edu/fbook07/fact_book_0708.pdf. [Accessed 18 March 2008].

42. Ibid., 37.

43. Indiana University Bloomington Libraries, "About the IUB Libraries." Available online at www.libraries.iub.edu/index.php?pageId=5425. [Accessed 23 August 2007].

44. Ibid.

45. Paul B. Kantor, Objective Performance Measures for Academic and Research Libraries (Washington, D.C.: Association of Research Libraries, 1984).

46. Blaine H. Hall, Collection Assessment Manual for College and University Libraries (Phoenix, Ariz.: Oryx Press, 1989), 44. 
47. Mansbridge, "Availability Studies in Libraries," 305.

48. Magazines for Libraries (15th ed.), ed. Cheryl LaGuardia (New Providence, N.J.: CSA, 2007).

49. This potential bias of using citations from dissertations is noted by Penny M. Beile, David N. Boote, and Elizabeth K. Killingsworth, "A Microscope or a Mirror?: A Question of Study Validity Regarding the Use of Dissertation Citation Analysis for Evaluating Research Collections," but the point would also apply to faculty publications and course reading lists.

50. Everett M. Rogers, Diffusion of Innovations, 5th ed. (New York, Free Press, 2003).

51. Indiana University Bloomington Libraries, "Request Materials from the Library Auxiliary Facility (ALF)." Available online at www.libraries.iub.edu/index.php?pageId=54. [Accessed 9 May 2008].

52. Mansbridge, "Availability Studies in Libraries," 305.

53. Nisonger, "A Review and Analysis of Library Availability Studies," 33.

54. Mansbridge, "Availability Studies in Libraries," 307.

55. Nisonger, "A Review and Analysis of Library Availability Studies," 49.

56. Steynberg and Rossouw, "The Availability of Research Journals in South African Academic Medical Libraries," 838.

57. Shaw-Kokot and Varre, "Using a Journal Availability Study to Improve Access," 24.

58. Chaudhry and Ashoor, "Comprehensive Materials Availability Studies in Academic Libraries," 302.

59. Bachmann-Derthick and Spurlock, "Journal Availability at the University of New Mexico," 197.

60. Roberts, "Journal Availability Study," 36.

61. Harris and Garner, "Using an Availability Survey to Improve Service at a University Library," 28.

62. Ciliberti et al., "Empty Handed? A Material Availability Study and Transaction Log Analysis Verification," 284.

63. Schaffer, "Psychology Citations Revisited," 354.

64. Price, "How Many Journals Do We Have?" 136.

65. Squires, Moore, and Keesee, "Electronic Journal Availability Study," 2.

66. These data were sent to the author in an e-mail from Stephen E. Wiberley, Jr. on November 16, 2007.

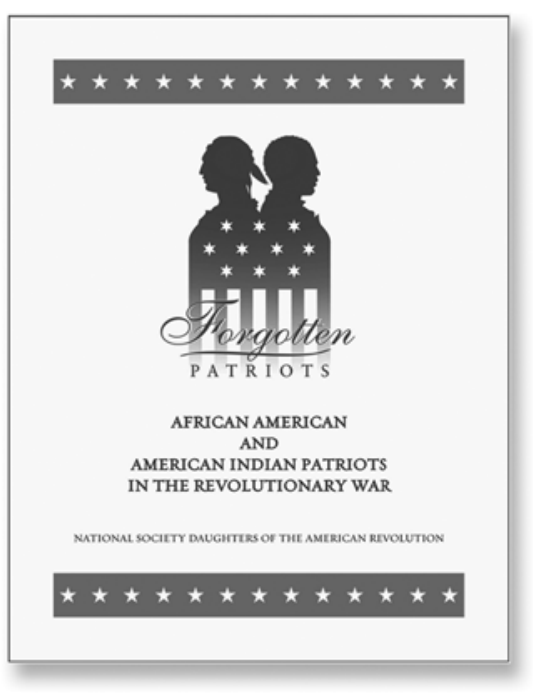

$\$ 35$ Plus $\$ 8$ S\&H

\section{New Revolutionary War Resource Guide Now Available}

An unprecedented new publication highlighting the contributions of African Americans and American Indians in America's War for Independence is now available from the Daughters of the American Revolution.

- Identifies over 6,600 names of African Americans and American Indians who contributed to American Independence

-9" x 12" hardbound book, 872 pages

- Contains details of documented service, historical commentary and an extensive bibliography of research sources related to the topic

\section{Order your copy today from}

\section{The DAR Store, 1776 D Street NW, Washington, DC 20006 (888) 673-2732 or www.dar.org/darstore}




\section{Appendix A \\ Source Journals for the 50 Subject Areas}

\section{Area Studies}

African American Studies - Journal of African American History

African Studies-African Studies Review

American Studies-American Quarterly

Central Eurasian Studies-Central Asiatic Journal

East Asian Studies-China Quarterly

Jewish Studies-Jewish Studies Quarterly

Latin American \& Caribbean Studies-Journal of Latin American Studies

Russian \& East European Studies - Slavic Review

West European Studies-European History Quarterly

Women's Studies - Signs: Journal of Women in Culture and Society

\section{Humanities}

Art-Art Journal

Classical Studies-Greece and Rome

Dance-Dance Research

English and American Literature-American Literature

Folklore-Journal of Folklore Research

French-French Studies

Music-Journal of the American Musicological Society

Philosophy-American Philosophical Quarterly

Religion-Journal of Religion

Theatre and Drama-Theatre Journal

\section{Professional Fields}

Business-Academy of Management Review

Education-American Educational Research Journal

Journalism - Harvard International Journal of Press-Politics

Law-Harvard Law Review

Library Science-College $\mathcal{E}$ Research Libraries

Medicine-New England Journal of Medicine

Nursing - Nursing Research

Optometry-Optometry and Vision Science

Public Administration-Public Administration Quarterly

Social Work-Social Work

\section{Science}

Astronomy-Astrophysical Journal

Biology - FASEB Journal: The Journal of the Federation of American Societies for Experimental Biology

Chemistry-Journal of the American Chemical Society

Computer Science-Journal of the Association for Computer Machinery

Environmental Sciences-Environmental Science and Technology

Geology-Journal of Metamorphic Geology

Information Science-Journal of the American Society for Information Science and Technology

Mathematics - American Journal of Mathematics

Neuroscience-Nature Reviews Neuroscience

Physics-Physical Review A 


\section{Social Sciences}

Anthropology-American Anthropologist

Criminology-Criminology: an Interdisciplinary Journal

Economics-Quarterly Journal of Economics

Geography-Annals of the Association of American Geographers

History-American Historical Review

International Relations - International Organization

Linguistics - Journal of Linguistics

Political Science-American Political Science Review

Psychology-Psychological Bulletin

Sociology-American Sociological Review

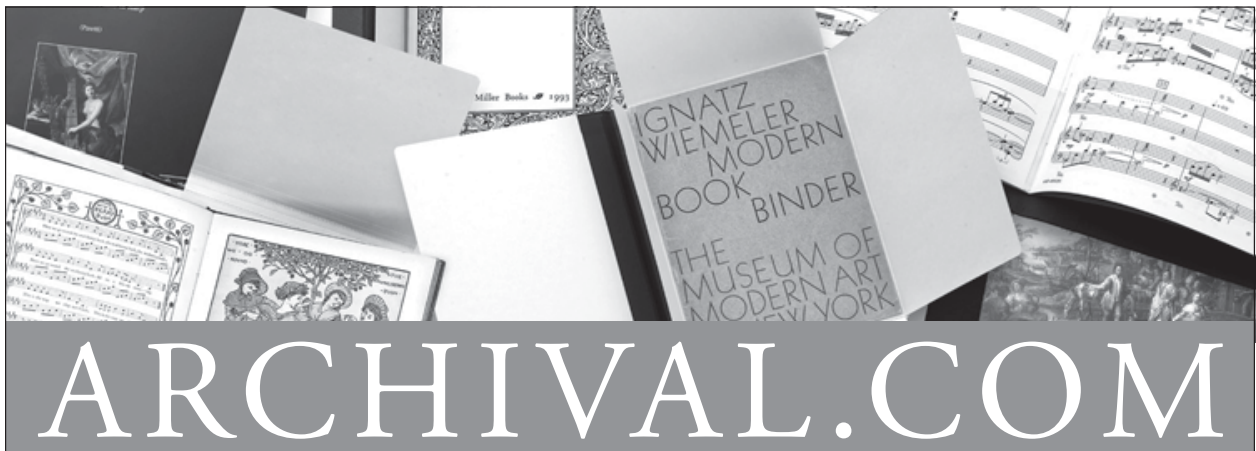

INNOVATIVE SOLUTIONS FOR PRESERVATION

Call for a complete catalog

Pamphlet Binders Music Binders Archival Folders Manuscript Folders Hinge Board Covers Academy Folders Newspaper/Map Folders Bound Four Flap Enclosures Archival Binders
Polypropylene Sheet \& Photo Protectors Archival Boards Adhesives

Bookkeeper Century Boxes Conservation Cloths Non-Glare Polypropylene Book Covers CoLibri Book Cover System
ARCHIVAL PRODUCTS

P.O. Box 1413

Des Moines, Iowa 50306-1413

Phone: 800.526 .5640

Fax: 888.220.2397

E-mail: custserv@archival.com Web: archival.com 